\title{
Theorising Europeanisation in European Literature: Conceptualisation and Operationalisation
}

\author{
DAVITI MTCHEDLISHVILI \\ University of Canterbury \\ daviti.mtchedlishvili@pg.canterbury.ac.nz
}

\begin{abstract}
There has been an extensive academic debate on the impact of the European Union on its member states, on the candidate countries for EU membership and the countries in its geographical neighbourhood. This paper analyses the notion and working conceptualisation of 'Europeanisation', which is to say, the EU's impact on domestic political systems, when EU rules, norms and laws are first defined and consolidated in the making of EU decisions and then incorporated in the logic of domestic discourse, identities, political structures and public policies. The paper suggests to analyse the Europeanisation process in three ways. Moreover, the article elucidates the gradual development of the Europeanisation theory from so called "internal" to "external" Europeanisation, whereby the EU tries to transfer its Acquis Communautaire (the legal order of the European Union) to the international level. However, research on the Western understanding of Europeanisation confirms that the analysis of the process, when the European neighbourhood states adopt the EU acquis (the objectives of the European Union, its policies and the rules governing these policies) from the viewpoint of institutional framework has significant limitations. To deal with some of these issues, the paper outlines the conceptualisation of Europeanisation and examines the difference between Europeanisation and European Integration.
\end{abstract}

Keywords: Candidates, EU, Europeanisation, European Integration, Neighborhood

\section{The Notion and Conceptualisation of European Integration and Europeanisation}

Scholars have been trying to better understand how the EU influences across time and space domestic political and social processes of the member states and beyond. Jensen and Kristensen (2012) point out in their paper, referring to Puchala's (1972) metaphor ${ }^{1}$ on blind men and elephants, in which the European Commission - is the metaphor of the elephant and the scholar - being the blind men. Each blind man felt the different parts of the elephant and hence, understood it in a different way. They offered a different description of the "beast" based on the part of the animal they touched. Using this logic, Puchala urged a search for a joint theoretical effort to understand the whole phenomenon beyond its single parts (Falkner, 1998).

\footnotetext{
${ }^{1}$ See further: Donald Puchala (1972) Of Blind Men, Elephants and International Integration. Journal of Common Market Studies. Vol. 10, N. 3, pp. $267-284$.
} 
.... scholars coming from different theoretical traditions, touch upon different parts of the elephant and thus portray a very different beast.... None of them are mistaken, but none of them have the complete picture either (p. 267).

At first glance, the concepts - European Integration and Europeanisation seem to be similar. However, as Radaelli (2000) argued, Europeanisation should not be identified with neither harmonisation nor convergence. Undoubtedly, the concept of European Integration has played an important role in the theoretical analysis of the EU, as it reflects the development of the European Coal and Steel Community through to the European Union (Mikkelsen, 1991). Furthermore, European Integration began in 1950 with the Schuman Plan which launched the European Coal and Steel Community. Its supporters expected integration to expand beyond coal and steel and looked forward to deeper European Integration. Technical and functional integration within Europe, as was inspired by Jean Monnet's vision, could lead to political transformation.

European Integration is traditionally defined as the convergence of relations between the various elements (the elements of the institutional structure) and institutions and/or strengthening the relationship itself, that is the intensification of any communications in the European orbit (Howell, 2002). In fact, the term European Integration refers to the process of creating European institutions and policies, whereby policies are increasingly shaped and set at the European level and impact on national governments and wider civil society (McGowan, 2007) towards the formation of a supranational centre, around which is constituted a common European space. In some definitions, it is difficult to distinguish between European Integration and Europeanisation. As Olsen (2002) argues, European Integration and Europeanisation are the same thing, and from the perspective of the EU it is a political project in the context of unification. However, the processes of Europeanisation and European Integration have been considered two distinct phenomena and while the EU has matured as a political system, these two phenomena have developed reflexive or dependent relationships, necessitating a reconsideration of the research agenda for both phenomena (Ladrech, 2014). From Radaelli's (2000) perspective Europeanisation is not political integration and Europeanisation would not exist without European Integration. He argues that the Europeanisation concept belongs to the ontological stage of research, that is, the understanding of a process in which countries pool together sovereignty (Radaelli, 2000).

In contrast to European Integration, Europeanisation is not a sui generis (unique) phenomenon, rather it is conceptualised in a way that makes it "possible to compare European dynamics with the dynamics of other systems of governance" (Olsen, 2002, p. 922). Olsen (2002) suggests differentiation of the concept with what, why and how questions. In particular, what is changing and how and why Europeanisation takes place. Furthermore, he identified Europeanisation as the changes that take place in member states and quantifies processes of institutional change and how/why they take place.

Europeanisation can be interpreted in three ways. First, as the emergence and development at the European level of the various structures - meaning the political, legal and social institutions (Risse, et al., 2001). This process includes institutionbuilding at the European level and explores how the Europeanisation process impacts the member states. In this approach, the level of analysis is the domestic system and the main objective of the study is the impact of the EU (Grabbe, 2006). 
Secondly, the concept of Europeanisation can be seen as an incremental process while political and economic dynamics become part of the organisational logic of national politics and policy-making (Ladrech, 1994). By 'organisational logic' Ladrech means the 'adaptive processes of organisations to a changed or changing environment' (Ladrech, 1994). This scholarship of Europeanisation emphasises that the actions of pan-European institutions may have different consequences and results in the member states and that the EU's influence at the national level depends not only on the effectiveness of the functioning of its institutions, but also on specific national factors. The object of Europeanisation is not limited to national politics and one could add national identities (Radaelli, 2000). By contrast, this definition accommodates both organisations and individuals and covers the political structure, public policy, identities and the cognitive dimension of politics (Radaelli, 2000). This interpretation suggests two types of Europeanisation - the "top down" and "bottom up". "Top down" or a process of downloading ( Börzel \& Risse, 2000) seeks to explain the conditions and casual mechanisms through which the EU triggers domestic change (Börzel \& Panke, 2016). It quantifies that EU policies and institutions are a constant impetus of domestic change for all states (Cowles, et al., 2001). The top-down approach uses the concept of "downloading" to elucidate how the member states or the third countries can be good at (downloading) EU policies and implementing them into their national politics (Börzel \& Panke, 2016). Top-down Europeanisation occurs, for example, with the European Central Bank through the establishment of pan-European indicators of price stability. This is the so called "financial integration" that requires selected policy implementation for the member states to avoid prolonged inflation and deflation and achieve high levels of economic activity and employment (European Central Bank, 2017).

On the other hand, "Bottom up" Europeanisation or up-loading analyses shows how states upload their domestic preferences to the EU level (Howell , 2002). An EU member state is a successful "uploader" if it manages to make its preferences heard so that EU policy, political process or institution reflects its interests (Börzel \& Panke, 2016). The member states in their reform strategies try to be original with their character models to provide a way to solve their own problems, and to ensure the transfer of specific elements of the local political system at the EU level.

The third interpretation of the term - "Europeanisation" - summarises the previous two definitions, namely, the development and consolidation of certain institutions and practices at the EU level as well as on their national political systems (Olsen, 2002). This process relates not only to the political system as a whole but also its individual components, and in particular the rules, paradigms, policies and political programs of the member states. Thus, Europeanisation is defined as the design, diffusion and institutionalisation of formal and informal procedures, beliefs and norms which are first defined and consolidated in the process of developing common European Union decisions and then incorporated into the local discourse logic, identities, political structures and public policies (Radaelli, 2000). This effect of Europeanisation can be conceptualised as a process of change at the domestic level in which the member states adapt their institution, policies and processes to new practices, rules, norms and procedures through different mechanisms of institutional change ( Börzel \& Risse, 2000). This approach stresses the importance of change in the logic of political behaviour, which gives the opportunity to distinguish Europeanisation effects from the many other processes of change in the post-communist political context (Grabbe, 2006). Nevertheless, this type of Europeanisation studies not only the members of the 
European Union, but also the countries beyond the Union - to the candidate countries for the European Union membership or/and the European Union neighbouring countries.

\section{Europeanisation: EU "hits neighbours' homes"}

Sustained interest towards Europeanisation emerged in the late 1990s in the study of the dynamics of integration in the European Union. As Borzel and Risse argue, the scholarship of Europeanisation has become a "cottage industry", exemplified by various edited volumes ( Börzel \& Risse, 2000). For that reason, Olsen (2002) argued that Europeanisation was a fashionable term for which there were many definitions. Europeanisation might have been a fashionable term but it needed further exploration, explanation and conceptualisation (Howell, 2002). Furthermore, since the development of the Europeanisation, the concept has also been applied to investigate international conflicts. For example, an expert on relations between the European Union and Russia and the CIS countries, Emerson, estimates that the prospects for resolving European conflicts in the formation of a common European political space and expand the influence of "political Europe" borders (Emerson, 2004). This scholarship studies European regional conflicts by taking into account continued Europeanisation and the integration in Europe (Noutcheva, et al., 2004). A number of researchers seek to identify the degree of influence of the EU on cross-border conflicts through Europeanisation process and conceptualise the channels of influence of the European Union, which includes a range of deliberate, direct and indirect effects of integration (Noutcheva, et al., 2004; Diez, et al., 2006). Much of the literature on theoretical understanding of "external" Europeanisation, consider the EU's influence on international relations and international regimes. The remarkable work of specialists of the Institute of European Integration Studies contain an analysis of the measurements, mechanisms and results of the process of Europeanisation of EU's foreign policy (Müller \& de Flers, 2009). These working paper series, extend the theoretical bases of research of mechanisms of formation of the Common Foreign and Security Policy. The central added value of studying European foreign policy from Europeanisation perspective lies in the fact that Europeanisation concepts shift the attention to the interactions between the national and EU level in European foreign policy (Müller \& de Flers, 2009). Meanwhile, the range of research on "external" aspects of Europeanisation remains small, and their conceptualisation is fragmented. Theorists of the "internal" Europeanisation (see e.g. Olsen (2002), Borzel and Risse (2003), Radaelli (2003) agree that the Europeanisation process may unfold not only within the EU but also outside its borders, but their works are limited to the study of the experience of the candidate countries for accession. Scholars have been studying the dynamics of the impact of Europeanisation and transformations of the internal politics of the states that has been linked to the enlargement of the European Union in 2004-07. This particular research focus had shifted to issues of adaptation of the future EU member states to the requirements to supranational institutions. However, over time, European researchers were not limited to considering only this experience. They also began to apply a "top-down" approach to analyze the impact of integration on the member states of the EU and the third countries. This type of Europeanisation has become increasingly referred to, not only in connection with the integration and regionalisation, but in the context of globalisation and democratisation (Flers, Patrick Müller and Nicole Alecu de, 2009). As Professor Radaelli indicates, there had been many attempts to develop a theory covering "top-down" and "bottom-up" approaches to Europeanisation and the study emphases of the concept had differed from the 
control groups to the focus of mechanisms (rather than variables) and the qualitative aspects in politics. (Radaelli \& Exadaktylos, 2009). Moreover, Radaelli and Exadaktylos examined the field of Europeanisation by looking at the control groups which contained a diverse set of journals on Europeanisation. The articles where chosen based on their high number of citations ${ }^{2}$.

Over time, the study has made a significant adjustment, not only in the research of the EU member states and the candidate countries to the EU membership, but also in relations with neighbouring countries, for the development of co-operation, which was, in particular, initiated by the European Neighbourhood Policy (ENP) in 2003-04. From this perspective, the concept - Europeanisation - should be considered as a framework concept, which is interrelated with external aspects of European Integration. It is the process of spreading the EU laws, rules, values, legislation and practices, as well as forms of political control not only within the EU but also outside its borders (Lavenex \& UçArer, 2004).

Therefore, the study of the external dimension of the Europeanisation has turned into an independent area of research. The starting point in this sense has become a vast reservoir of Western academic literature focused on the comparative analysis of changes in the EU accession candidate countries in 2004-07 (Sedelmeier, 2006). This scholarship was developed by Swiss experts Schimmelfennig and Sedelmeier, who began to study the issues with the reliance on the provisions of New Institutionalism. (Schimmelfennig \& Sedelmeier, 2004). In fact, the proponents of New Institutionalism affirm that the choices of individual political actors cannot be understood in a vacuum, but must be placed in specific institutional contexts (Harmsen, 2000). What is more, New Institutionalism studies political institutions, as a set of theoretical ideas and elucidates the relations between institutional characteristics and political agency, performance and change (Olsen, 2009). Based on these premises, Schimmelfennig and Sedelmeier analysed rule transfer and the adoption of EU acquis in non-member states, i.e. their institutionalisation at the domestic level. Such institutionalisation includes the transfer of EU legislation into domestic law, the restructuring of domestic institutions according to EU rules, or the change of domestic political practices according to EU standards (Schimmelfennig \& Sedelmeier, 2004).

The process of the Eastern enlargement of the EU and the creation of the European Neighbourhood Policy (ENP) in 2003-04 initiative and later the Eastern Partnership Program (EaP) in 2009, significantly stepped up theoretical studies of the EU's ability to integrate and influence beyond its formal boundaries. Hence, Europeanisation is not conceptually limited to the impact of the EU on its' member states (Graziano \& Vink, 2007). Furthermore, it is relevant to assume that the EU has an impact on member states, quasi-member states that participate in the internal market of the EU and the candidate states that must adopt EU rules, norms, laws to qualify for membership (Schimmelfennig, 2012). But can the EU also have a systematic and distinctive influence beyond its borders? (Schimmelfennig, 2012; Lavenex, 2004).

In fact, after the academic debate of the 2000s about the analytical framework of governance and boundaries in the central and Eastern European countries (CEEC) and the Politics of Enlargement (Friis \& Murphy, 1999) or later in 2002 by Filtenborg et al., Lavenex developed the concept of External Governance and the idea that

${ }^{2}$ See Radaelli, C. M. \& Exadaktylos, T., 2009. Research Design in European Studies: The Case of Europeanization. Journal of Common Market Studies, Volume 47, pp. 507-530. 
Europeanisation "reaches" all EU neighbourhood countries (Lavenex, 2004) without a membership agenda by offering everything but institutions (Prodi, 2002). Whereas the EU uses the incentive of membership as the effective lever to make applicant countries adopt its rules, at least formally, this instrument is not applicable to countries from the European Neighbourhood Policy. Furthermore, the European Neighbourhood Policy and the Eastern Partnership Program (which is the Eastern dimension of the ENP) do not guarantee membership of the European Union. Rather it is a totally voluntary process without binding laws unlike accession (enlargement) countries (Western Balkan) where the acquis communautaire adopted in Brussels are regulatory.

Moreover, the concept of Europeanisation has an external dimension (Lavenex \& UçArer, 2004). As a result, the scholarship of Europeanisation crossed the borders of the European Union and since then, the study has been generally referring to the process of various political and institutional changes of the states beyond the EU borders under the pressure of European Integration process (Schimmelfennig, 2012). Several scholars have attempted to define the conditions of Europeanisation for its effectiveness. Schimmelfennig (2012) identifies market power and supranational regulation as an important condition for effectiveness or credibility of its conditionality, when partner countries expect to receive the rewards if the conditions are met (Schimmelfennig \& Sedelmeier, 2004). On the other hand, the EU has the effect of creating a policy space for new initiatives on the political agenda by causing institutional adaptations that have an effect on the policy-making process (Grabbe, 2006). Another condition for effectiveness for the Europeanisation is the process of socialisation. During this process, the EU instructs partner countries in the principles and rules of European governance through social channels (Freyburg, et al., 2007). In other words, the external actors accept or do not accept the authority of the EU and adopt and comply or not with EU rules. For an effective Europeanisation process, the EU has to be able to rely on administrative structures and expertise in the partner countries. Such networks require strong administrative actors in partner countries (i.e. police official and border guards) "to succumb to the functional, problem-oriented dynamics of mutual learning and adaptation that the EU seeks to unleash" (Lavanex \& Wichmann, 2009, p. 97).

Based on the growing interest in the European scientific community to study the EU's international activities, Schimmelfennig (2012) has reviewed the bibliographic topics on external Europeanisation. The author has shown that, despite the fact that European researchers have focused mainly on the role of the EU as transforming civil or regulatory power, their interest often focuses on the relationship between the EU as a global centre of power with other regional groupings and leading countries of the world. The implementation of this approach was reflected in an idea of promoting a "European model of integration" and is based on the belief that the neo-liberal model of the economy, democratic values and legal norms of the EU, are able to stimulate the development of most countries and regions of the world (Schimmelfennig, 2012). 


\section{Differentiation of Europeanisation: Candidates and Neighbourhood}

Schimmelfennig and Sedelmeier, under the paradigm of Neo-Institutionalism, have been exploring the mechanisms and methods of the Europeanisation of the candidate countries for EU membership from Central and Eastern Europe based on two approaches (Schimmelfennig \& Sedelmeier, 2004). The first approach is based on the hypothesis that in the international arena, Europeanisation can be driven by the supranational or EU level. The second approach is guided by an "institutional" logic (March \& Olsen , 2004). The supranational level is built upon sanctions or/and incentives from the EU, that change the distribution of costs and benefits of potential candidate countries for EU membership. The national administrations of the candidate countries must implement legally binding EU rules to avoid sanctions or on the other hand receive rewards if they are successful in the implementation (Schimmelfennig, 2012).

This type of Europeanisation has the effect of, as Grabbe puts it, "empowering modernisers" to change specific policies and reform the political institutions (Grabbe, 2006). "Europe" has been claimed and used by elites as an external constraint to bypass national political and administrative systems and to enforce decisions and policies (Grabbe, 2006). Secondly, the principle of "matching" is an important condition for effective Europeanisation (Featherstone \& Radaelli, 2003). If European norms, rules, and laws are largely compatible with those at the domestic level, they do not give rise to problems of compliance or effective implementation (Borzel \& Risse, 2003). There must be some misfit (Börzel \& Risse, 2000) between European and domestic policies, institutions and processes. Another key factor is the credibility of EU conditionality (Sedelmeier, 2006). This includes receiving the promised rewards if the candidate countries for EU membership meet the EU's demands. The ultimate reward of EU membership is certainly "the best" benefit for candidates, though sometimes the rewards are long term. For instance, the EU can offer aid to the country if it fulfils the specific conditions (Sedelmeier, 2006). The conditions set out at the Copenhagen European Council in 1993 were designed to minimise the risk of new entrants becoming politically unstable and economically burdensome to the existing EU (Grabbe, 2006), The politics of accession within the EU is based on the principle of political conditionality - the obligation of all potential members of the EU to implement EU acquis communautaire (Legal norms and practices of the EU) at the national level. The only difference between the candidate countries for EU membership consist in the timing of the adaptation of these standards into domestic law. It is a fact that the EU has been firmer with its adhesion to the Copenhagen accession criteria for new candidates since the 2004-07 enlargement round, that has caused subsequent slower progress in association/accession and stagnation in post-communist reform (Petrovic, 2013). In 2006, the European Council introduced a tougher tool for the adoption and implementation of acquis chapters for the current and new membership candidate countries (Petrovic, 2013). As the European Parliament stated, the Western Balkan aspiring members are facing an additional set of politically sensitive conditions, often colloquially referred to as the 'Copenhagen Plus' criteria, which relate to the respect for and implementation of various political and peace agreements stemming mostly from the armed conflicts of the 1990s (European Parliament, 2015).

However, the principle of political conditionality has a chance of practical implementation in the presence of tangible prospects of membership (Sedelmeier, 2006; Schimmelfennig, 2004), especially when the internal costs (democratic 
standards, legislation and EU practices) are not too high and do not threaten the stability of these states.

The process of transferring the EU Acquis Communautaire to third countries is an indispensable part of the challenging Europeanisation. This process could be quite perplexing, because EU initiatives might be directed towards the countries that do not identify with a common European space (for instance countries from the European Neighbourhood Policy), and/or want to preserve their system of values, their individual ways of developing integration processes in ways different to those favoured by the EU. Indeed, the adoption of the acquis should encourage third countries to share the 'Union's common values' (Leino \& Petrov, 2009). To put it another way, the willingness of the partner countries to engage with the EU is a pre-condition for conditionality to work. Faced with the transformation of their national politics, the governments of third countries engage in cost/benefit calculations that should then lead them to align (or not) domestic policy and behaviour with conditions set by the European Union (Checkel, 2000). Furthermore, the reason why the national agents might not adjust their national politics is that democratic standards and EU practices might threaten the stability of their political regimes. The spread of democratic values is the basis of the EU's international activities because "external" Europeanisation fits into the logic of the democratisation process (Lavenex \& Schimmelfennig, 2011).

Conditionality is premised on a materialist ontology (money, material incentives) (Checkel, 2000) and third countries are supposed to receive financial and technical assistance (so-called carrots) if the EU conditions are met. Even though, national agents are often calculating their interests and preferences when seeking assistance. For this reason, political conditionality is weakened by a limited set of tools to induce the partner to commence a process of democratisation despite their week confidence in EU institutions, as well as the high internal costs associated with the transformation of (semi) authoritarian regimes (Schimmelfennig \& Scholtz, 2007). In this case, democratisation and successful transformation of third countries cannot be successfully "activated". Based on these premises, some researchers have focused on the study of alternative models of democracy assistance and promotion within the European Neighbourhood Policy, the concept of - Good Governance (Lavenex \& Schimmelfennig, 2011). This has caused a "renaissance" of the Neo-Functionalist approach, according to which the introduction of a democratic model of governance as part of the foreign policy of the European Union - should be carried out in separate political subsystems, so that later, due to the effect of "Spill-Over" (the concept is also known as 'snowball' effect) to democratise the entire national political space (Freyburg, et al., 2011). The central logic of Spill-Over is that integration within one sector will tend to beget its own impetus and spread to other sectors as well (Mikkelsen, 1991).

\section{Conclusion}

This paper attempts to re-assess the dilemma of conceptualising Europeanisation. At first, it recognises that in contrast to European Integration, Europeanisation is not a sui generis phenomenon, though, the concept is broad and 'conceptually stretchy'. Hence, the paper offers to draw limitations and suggests the interpretation of Europeanisation in three ways.

Firstly, it interprets Europeanisation as the convergence and development at the European level of various structures while the level of analysis is the domestic system 
and the main analytical set-up is to study the impact of the EU (Grabbe, 2006). This process includes institution-building at the European level and studies how the Europeanisation process impacts on the member states.

Secondly, this paper explored Europeanisation from the perspective of organisational logic of national politics when the EU's influence at the national level depends not only on the effectiveness of the functioning of its institutions but also on specific national factors (Ladrech, 1994). This definition accommodates both - organisations and individuals - and covers the political structure, public policy and identities (Radaelli, 2000).

The third interpretation - a compilation of the previous two- takes into account not only the political system as a whole but also its individual components, in particular, the rules, paradigms, policies and political programs of the states (Börzel \& Risse, 2000; Howell, 2002). This interpretation takes into account the local discourse logic, identities, political structures and public policies; it stresses the importance of change in the logic of political behaviour. This offers the opportunity to distinguish Europeanisation effects from the many other processes of change. This effect of Europeanisation can be conceptualised as a process of change at the domestic level in which the member states adapt their institutions, policies and processes to new practices, rules, norms and procedures through different mechanisms of institutional change (Börzel \& Risse, 2000). As indicated, this type of Europeanisation can be targeted at EU members and at the same time at countries outside the European Union, the candidate countries for European Union membership or/and the European Union's neighbouring countries.

The promise of accession (membership candidate countries) is more powerful than the promise of association (neighbourhood countries) and the impact of the EU on candidates for membership is stronger than on neighbouring states (Schimmelfennig \& Scholtz, 2007), although these two processes are similar from the perspective of the principle of political conditionality. The impact of the EU increases with the size and credibility of the EU's conditionality (conditional incentives), while it is weakened by a limited set of tools to induce the partner to commence a process of democratisation despite their week confidence in EU institutions. Further, the problem of a "conceptual challenge" is discussed and the paper argues that for a better understanding of external Europeanisation, one should take into account the EU's particular set of tools that aim to stimulate the partner countries to transform and democratise their national politics, as well as the high internal costs associated with the transformation of authoritarian and semi-authoritarian regimes. Hence, in order to influence and reform, the EU should provide additional incentives and resources, particularly, in the neighbourhood, where the membership perspective is missing from the picture.

\section{Bibliography}

Börzel, T. A. \& Panke, D., 2016. Europeanization. In: M. Cini, ed. European Union Politics. s.l.: Oxford University Press, pp. 114 - 120.

Börzel, T. A. \& Risse, T., 2000. When Europe Hits Home: Europeanization and Domestic Change. European Integration online Papers, 4(15), p. 3. 
Börzel, T. A. \& Risse, T., 2003. Conceptualising the domestic impact of Europe. In: K. Featherstone \& C. M. Radaelli, eds. The Politics of Europeanization. Oxford: Oxford University Press, pp. 50-81.

Börzel, T. A. \& Riise, T., 2010. Europeanization: The Domestic Impact of European Union Politics. In: Handbook of European Union Politics. London: SAGE Publication, p. 587.

Checkel, Jeffrey T., 2000a. Compliance and Conditionality. Working Paper Series oo/18. Oslo, Norway: ARENA Centre for European Studies, University of Oslo

Cowles, M. G., Caporaso, J. \& Risse, T., 2001. Transforming Europe: Europeanization and Domestic Change. 1st ed. New York: Cornell University Press.

Diez, T., Stetter, S. \& Albert, M., 2006. The European Union and border conflicts: the transformative power of integration. International Organization, pp. 563-593.

Emerson, M., 2004. Europeanisation \& Conflict Resolution Testing an Analytical Framework, Brussels: CEPS Policy Brief,

European Central Bank, 2017. Financial integration in Europe, Frankfurt: European Central Bank.

European Parliament, 2015. The Western Balkans and EU Enlargement: Lessons learned, ways forward and prospects ahead, Brussels: Policy Department, Directorate-General for External Policies.

Falkner, G., 1998. Political Theory and EU Politics. In: EU Social Policy in the 1990s. New York: Routledge, p. 50.

Featherstone, K. \& Radaelli, C. M., 2003. The Politics of Europeanisation. New York: Oxford University Press.

Filtenborg, M. S., Gänzle, S. \& Johansson, E., 2002. An Alternative Theoretical Approach to EU Foreign Policy: Network governance and the Case of the Northern Dimension Initiative. Cooperation and Conflict, 37(4), pp. 387-407.

Freyburg, T., Lavenex, S., Schimmelfennig, F. \& Skripka, T., 2011. Democracy promotion through Functional Cooperation? The Case of the European Neighbourhood Policy. Democratization, 18(4), pp. 1026-1054.

Freyburg, T., Skripka, T. \& Wetzel, A., 2007. Democracy Between the Lines? EU Promotion of Democratic Governance via Sector-Specific Cooperation. Challenges to Democracy in the 21st, p. 20.

Friis, L. \& Murphy, A., 1999. The European Union and Central and Eastern Europe: Governance and Boundaries. Journal of Common Market Studies, 37(2), pp. 211232.

Goetz, K. H. \& Meyer-Sahling, J. H., 2008. The Europeanisation of national political systems: Parliaments and executives. Living Reviews in European Governance, 3(2), pp. 4-22. 
Grabbe, H., 2006. The EU's Transformative Power: Europeanization through Conditionality in Central and Eastern Europe. New York: Palgrave Macmillan.

Graziano, P. \& Vink, M., 2007. Europeanization:New Research Agendas. London: Palgrave Macmillan UK.

Harmsen, R., 2000. Europeanization and Governance: A New Institutionalist Perspective. [Online]Available at: http://ceses.cuni.cz/ceses-93-version1-4_2_2.pdf, [Accessed 12 2018].

Howell, K., 2002. Developing Conceptualizations of Europeanization and European Integration: Mixing Methodologies. UACES Study Group on the Europeanization of British politics, p. 27.

Jensen, M. D. \& Kristensen, P. M., 2012. The elephant in the room: mapping the latent communication pattern in European Union studies. Journal of European Public Policy, 20(1), pp. 1-20.

Ladrech, R., 1994. Europeanization of Domestic Politics and Institutions: The Case of France. Journal of Common Market Studies, 32(1), p. 71.

Ladrech , R., 2014. Rethinking the Relationship between Europeanization and European Integration. In: R. Coman, T. Kostera \& L. Tomini, eds. Europeanization and European Integration. London: Palgrave Macmillan, p. 15.

Lavenex, S., 2004. EU external governance in 'wider Europe'. Journal of European Public Policy, 11(4), pp. 680-700.

Lavenex, S. \& Schimmelfennig, F., 2009. EU rules beyond EU borders: theorizing external governance in European politics. Journal of European Public Policy, 6(16), pp. $791-812$.

Lavenex, S. \& Schimmelfennig, F., 2011. EU Democracy Promotion in the Neighbourhood: From Leverage to Governance? Democratization, pp. 885-905.

Lavenex, S. \& UçArer, E. M., 2004. The External Dimension of Europeanization. Cooperation \& Conflict, pp. 417-43.

Lavanex, S. \& Wichmann, N., 2009. The External Governance of EU Internal Security. Journal Of European Integration, 31(1).

Leino, P. \& Petrov, R., 2009. Between 'Common Values' and Competing UniversalsThe Promotion of the EU's Common Values through the European Neighbourhood Policy. European Law Journal 15(5): 654-671.

March, G. J. \& Olsen, P. J., 2004. The logic of appropriateness. ARENA Centre for European Studies.

McGowan, L., 2007. Theorising European Integration: revisiting neofunctionalism and testing its suitability for explaining the development of EC competition policy?. European Integration Online Papers, 11(3), p. 2. 
Mikkelsen, J. T., 1991. Neo-functionalism: Obstinate or Obsolete? A Reappraisal in the Light of the New Dynamism of the EC. Journal of International Studies, 20(1), pp. 1-22.

Müller, P. \& de Flers, N. A., 2009. Applying the Concept of Europeanization to the Study of Foreign Policy: Dimensions and Mechanisms. Institute for European Integration Research, p. 32.

Noutcheva, G. et al., 2004. Europeanization and Secessionist Conflicts: Concepts and Theories. Journal of Ethno Politics and Minority Issues in Europe, Volume 1, pp. 135 .

Olsen, J. P., 2002. The Many Faces of Europeanization. JCMS, 4O(5), pp. 921-952.

Olsen, J. P., 2009. Change and continuity: An institutional approach to institutions of democratic government. European Political Science Review, 1(o1), pp. 3-32.

Petrovic, M., 2013. The Democratic Transition of Post-Communist Europe: In the Shadow of Communist Differences and Uneven EUropeanisation. London: The Palgrave Macmillan.

Petrovic, M. \& Klatt, M., 2015. The European Union and its post-communist neighbours: EU enlargement and the European Neighbourhood Policy. In: N. Witzleb, A. A. Martínez \& P. Winand, eds. The European Union and Global Engagement: Institutions, Policies and Challenges. Cheltenham: Edward Elgar Publishing Limited, pp. 197-215.

Pridham, G., 2005. Designing Democracy: EU Enlargement And Regime Change in Post-Communist Europe. New York: Palgrave Macmillan.

Prodi, R., 2002. A Wider Europe - A Proximity Policy as the key to stability, Brussels: European Commission.

Puchala, D. J., 1971. Of Blind Men, Elephants and International Integration. Journal of Common Market Studies, p. 267.

Radaelli, C. M., 2000. Whither Europeanization? Concept stretching and substantive change. European Integration online papers, 4(8), pp. 6-25.

Radaelli, C. M. \& Exadaktylos, T., 2009. Research Design in European Studies: The Case of Europeanization. Journal of Common Market Studies, Volume 47, pp. 507530 .

Risse, T., Caporaso, J. \& Cowles, M. G., 2001. Europeanization and domestic change. In: J. Caporaso \& T. Risse, eds. Transforming Europe: Europeanization and Domestic Change. New York: Cornell University Press, pp. 1-19.

Schimmelfennig, F., 2012. Europeanization beyond Europe. Center for Comparative and International Studies, pp. 1-31.

Schimmelfennig, F. \& Scholtz, H., 2007. EU Democracy Promotion in the European Neighborhood: Conditionality, Economic Development, and Linkage. Monreal, s.n., p. 31 . 
Schimmelfennig, F. \& Sedelmeier, . U., 2004. Governance by conditionality: EU rule transfer to the candidate countries of Central and Eastern Europe. Journal of European Public Policy, pp. 661-679.

Sedelmeier, U., 2006. Europeanisation in new member and candidate states. Living Rev. Euro. Gov, p. 23. 